\title{
Arnaud Bernardet, Les «Vieux Coppées» de Verlaine: histoire d'une manière
}

Damiano Sinfonico

\section{(2) OpenEdition}

\section{Edizione digitale}

URL: http://journals.openedition.org/studifrancesi/6048

DOI: $10.4000 /$ studifrancesi.6048

ISSN: 2421-5856

\section{Editore}

Rosenberg \& Sellier

\section{Edizione cartacea}

Data di pubblicazione: 1 mai 2011

Paginazione: 199

ISSN: 0039-2944

\section{Notizia bibliografica digitale}

Damiano Sinfonico, «Arnaud Bernardet, Les «Vieux Coppées» de Verlaine: histoire d"une manière», Studi Francesi [Online], 163 (LV | I) | 2011, online dal 30 novembre 2015, consultato il 14 janvier 2021. URL: http://journals.openedition.org/studifrancesi/6048 ; DOI: https://doi.org/10.4000/studifrancesi.6048

Questo documento è stato generato automaticamente il 14 janvier 2021.

\section{(c) $(1) \&$}

Studi Francesi è distribuita con Licenza Creative Commons Attribuzione - Non commerciale - Non opere derivate 4.0 Internazionale. 


\title{
Arnaud Bernardet, Les «Vieux Coppées» de Verlaine: histoire d'une manière
}

\author{
Damiano Sinfonico
}

\section{NOTIZIA}

ARNAUD BERNARDET, Les «Vieux Coppées» de Verlaine: histoire d'une manière, in «Romantisme. Revue du dix-neuvième siècle», n. 148, Ie trimestre 2010.

1 L'A. individua nei Vieux Coppées una proposta critica sulla dicibilità poetica, sulla sua appropriazione di materiali nuovi che vengono rovesciati ed esibiti in un discorso antifrastico sulla "maniera". Se la perfezione dei versi è paragonata a quella delle fette di un salame, la loro lingua preleva ai margini della lingua letteraria per affondare in una zona periferica che porosamente si lascia conquistare e ibridare, andando a formare le fila di un nuovo linguaggio, anti-poetico, costruito come un «pastiche infâme d'une lyre / dûment appréciée entre tous gens de goût»: il Verlaine che si scaglia contro le maniere e si fa tentare dal silenzio, quello che sarà presto cantato in Sagesse, trova nell'anti-letterarietà lo strumento per demistificare l'artificio di ogni maniera e di ogni buon gusto, svalicando il crinale in un terreno linguistico dove la dialettica tra norma ed errore si riduce fino a scomparire. Insomma, un Verlaine contro la maniera di Coppée, ma anche intenzionato, in tempi successivi, a canzonare la propria maniera, a "deverlainiser" se stesso. 